\title{
Characteristics of Ourmia melon virus (OuMV) MINA RASTGOU
}

Department of Plant Protection, Urmia University, Urmia, Iran

(Corresponding author: m.rastgou@urmia.ac.ir)

Received: 13.04.2017

Accepted: 17.08.2017

Rastgou M. 2018. Characteristics of Ourmia melon virus (OuMV). Plant Pathology Science 7(2): 34-46. DOI :10.2982/PPS.7.2.34

Abstract: Ourmia melon virus $(\mathrm{OuMV})$ is one of the viruses that cause mosaic disease in melon (Cucumis melo L.), in West-Azerbaijan Province and some other parts of Iran including Guilan, Fars and Alborz Provinces. This virus was first detected in diseased cucurbits with mosaic and ring spot symptoms, in Urmia in 1978. The virus has unique characteristics that differentiate it from other viruses that infect cucurbits. The virus particles are bacilliform with conical ends. Genome consists of three linear positive-sense single-stranded RNAs, each encoding one protein. Host range mostly limited to Cucurbitaceae and Solanaceae families. Ourmia melon virus, Epirus cherry virus and Cassava virus $C$ are three species those are placed in the genus Ourmiavirus.

Key words: Melon, Mosaic, Ringspot, Narnaviridae

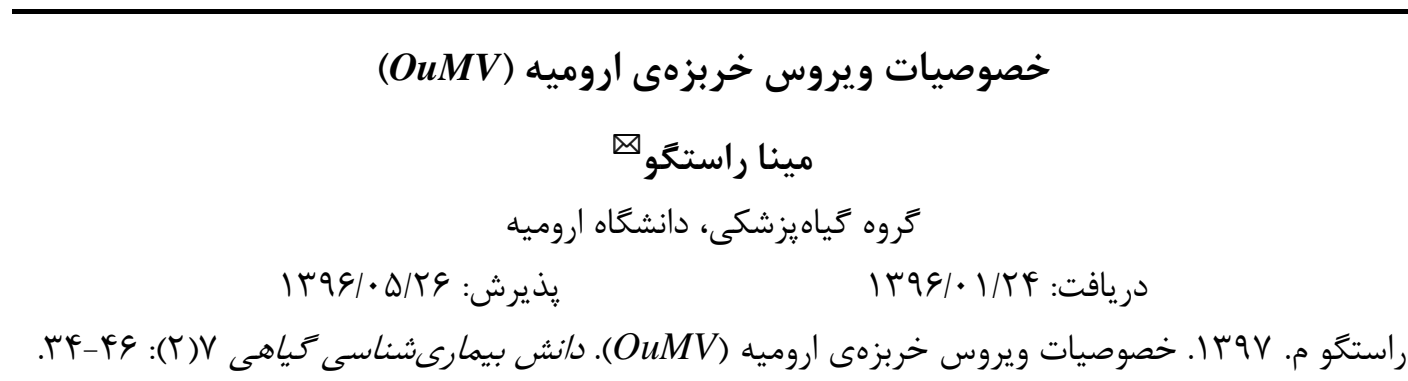

DOI :10.2982/PPS.7.2.34

جكيده: ويروس خربزهى اروميه يكى از عوامل بيمارى موزاييك خربزه (Cucumis melo L) در استان

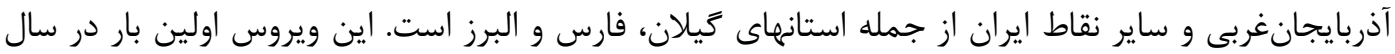

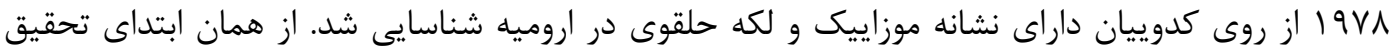

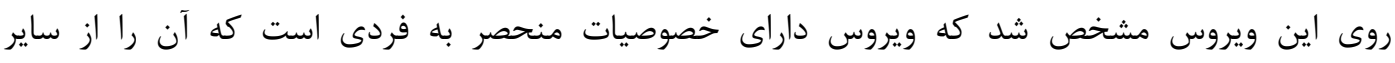

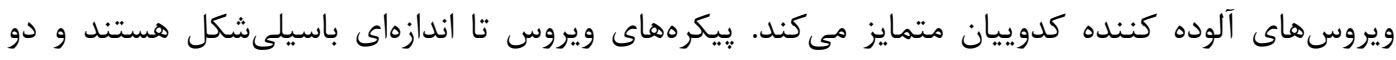

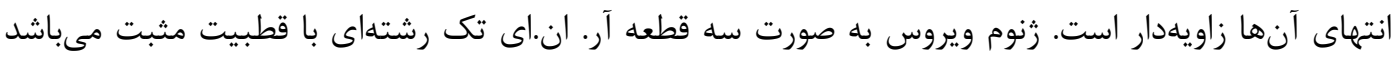

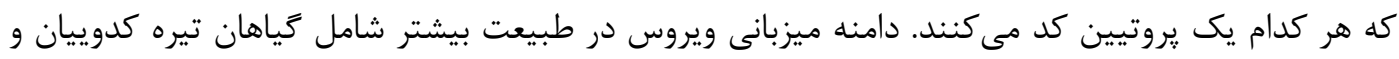

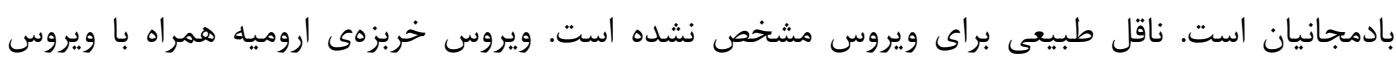

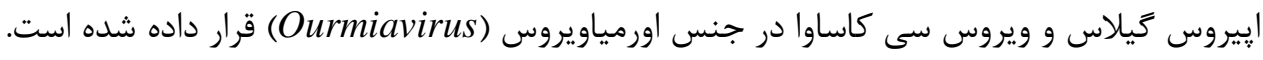

وازههاى كليدى: خربزه، موزاييك،لكهحلقوى، Narnaviridae 
ويروس خربزهى اروميه (Ourmia melon virus, OuMV) در استان آذربايجانغربى (راستكو و

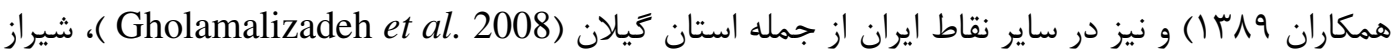
و كرج از ويروسهاى آلودهننده كدوييان محسوب مىشود (راستخو و همكاران 91٪(). بر اساس تفاهم Torino, ( همكارى بين مركز تحقيقات اروميه و مركز تحقيقات بيمارىهاى ويروسى گياهى در تورين ايتاليا (Italy در سال 1911 تعدادى نمونه كدوييان با نشانه موزاييك و لكه حلقوى از مزارع اطراف اروميه جمع آورى و به اين مركز فرستاده شد (Lisa et al. 1988a, b). از \&\& نمونه فرستاده شده، لا نمونه آلوده به ويروس خربزه اروميه بودند (Caciagli et al. 1989). در سال ra19 ا يك بيمارى شبه ويروسى روى گيلاس (Prunus avium L.) در باغى در إيبروس (Giannina) در شمال غرب يونان تزارش شد كه بعدها نام عامل بيمارى ويروس إيروس گيلاس (Epirus cherry virus, EpCV) نامگذارى شد. جنس Ourmiavirus

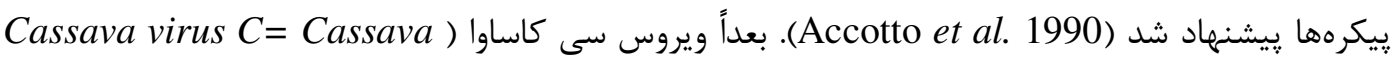
از كياه كاساواى (Ivorian bacilliform virus, CsVC موزاييك آفريقايى كاساوا (African cassava mosaic virus) در Touresso (ساحل عاج) جداسازى و به عنوان كونه سوم به اين جنس اضافه كرديد (Accotto et al. 1990, Rastgou et al. 2011). بعدها مشخص شد كه سيتوياتولوزى سلولهاى آلوده به OuMV و CsVC شبيه است اما با بقيه ويروسهاى شناخته شده روى اين كياهان تفاوت دارد (سيتوياتولوزى EpCV گزارش نشده است). دامنه ميزبانى آزمايشگاهى هر سه ويروس كه با مايهزنى مكانيكى تعيين شده است شبيه است و نشانهها معمولاً شامل لكه حلقوى سيستميك، ييسك، موزاييك و نكروز روى برى مىباشد. زنوم اين ويروسها از سه قطعه RNA تكلاى مثبت تشكيل شده كه در سه ويروس اندازه مشابهى دارند. اين سه ويروس در سه گَنه متفاوت قراركرفتند: با توجه به اينكه اين سه ويروس در طبيعت دامنه ميزبانى هميوشانى ندارند (بترتيب شامل: كدوييان، گيلاس، كاساوا)، يروتيين يوششى OuMV و EpCV تنها ارتباط سرولوزيكى دورى با هم دارند و اندازه آنها نيز با هم فرق دارد. OuMV بيز ارتباط سرولوزيكى ندارد (Accotto et al. 1990). 


\section{|-مشخصات بيكر ههاى ويروس}

ييكرههاى ويروس تا اندازماى باسيلىشكل (quasi-bacilliform) هستند اما انتهاى كرد نداشته و دو

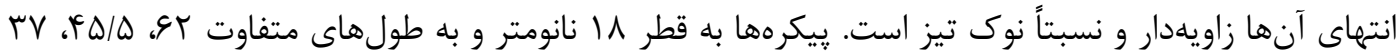
و • • نانومتر مىباشند. قسمت استوانهاى ييكره حاوى رديفهايى از ديسكهاى دوتايى است. متداولترين

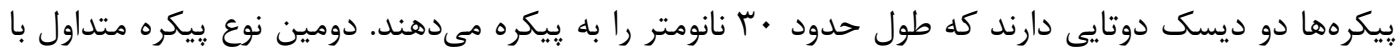

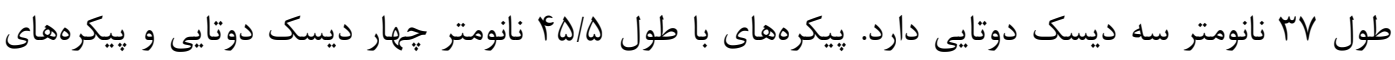

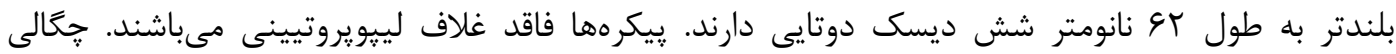

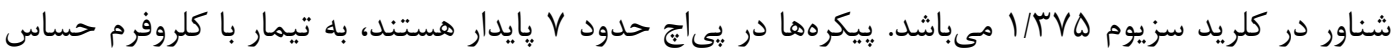
نبوده ولى به تيمار با ان- بوتانول حساس هستند (Lisa et al. 1988b, Rastgou et al. 2011). كربوهيدرات و ليييد در يِكره شناسايى نشده است. وزن مولكولى و ضريب رسوب ويريونها مشخص نيست (Rastgou et al. 2011). عصاره كياه آلوده بعد از • (1 دقيقه در دماى كننده بوده است. اين نتايج نشان مىدهد كه يِيكرها پايدارى نسبتاً خوبى دارند ) Lisa et al. 1990, Rastgou et al. 2011 ويروس در سيتويلاسم سلولهاى پارانشيم گياه آلوده و كاهى اوقات بصورت ساختارهاى pad-like و داخل لولهها (tubules) قابل شناسايى هستند (شكل () (Milne and Masenga 1988, 1989).

\section{ז-دامنه ميزبانى ويروس}

ويروس در شرايط آزمايشكاهى به آسانى به دامنه وسيعى از گياهان محك به طور مكانيكى قابل انتقال بوده و در اكثر آنها نشانهاى مشخصى را ايجاد كرده است. ويروس باس گونه از عا تيره گياهى را آلوده مى كند. در اثر مايهزنى با ويروس تعداد زيادى لكه موضعى روى Chenopodium quinoa Willd. Nicotiana clevelandii A. Gray در عرض ץ-ץ روز ايجاد مىشود. روى Gomphrena globosa L. نشانهاى لكه موضعى بعد از F-Y روز و موزاييك نكروتيك سيستميك بعد از Y-V روز ظاهر مىشوند. 


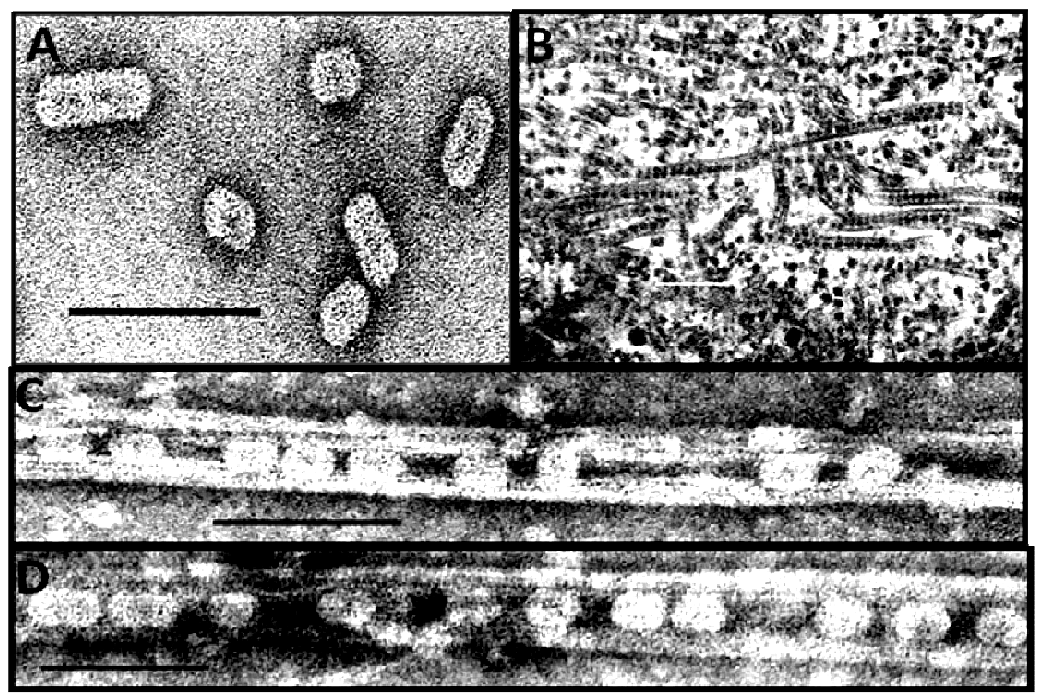

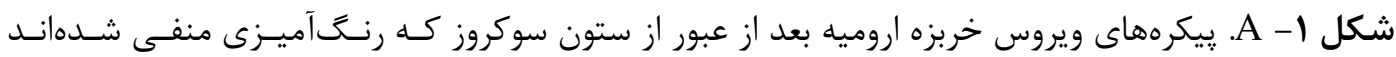

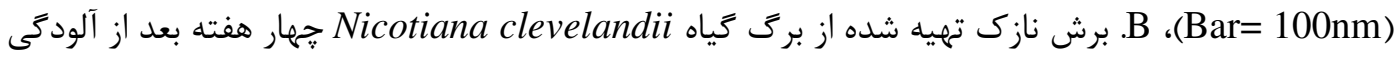

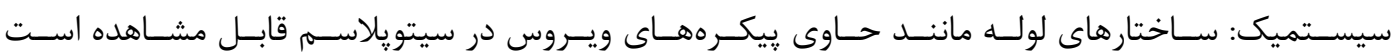

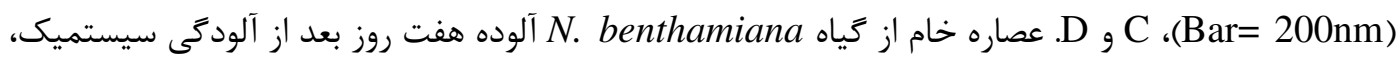

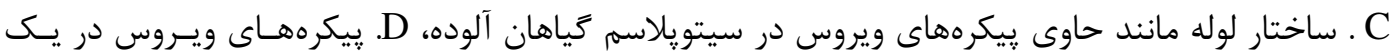
رديف پشت سر هم در داخل لوله قراركرفتهاند (Bar= 100nm).

Figure 1. A. Oumia melon virus particles after negative staining (Bar= $100 \mathrm{~nm}$ ), B. Thin section of leaf tissue from a 4 week systemic infection in Nicotiana clevelandii showing cytoplasm with tubules containing virus particles (Bar= $200 \mathrm{~nm}$ ), C and D. Crude sap extract of a 7 day systemic infection in $N$. benthamiana, C. A tubule containing virus particles in cytoplasm of infected plants, D. Virus particles laid in a row $($ Bar $=100 \mathrm{~nm})$.

N. megalosiphon Van Heurck and و N B. benthamiana Domin نشانهاى مشابهى روى

Capsicum annuum ايجاد مىشود. آلودگى روى گوجهفرنكى (Solanum lycopersicum)، فلفل Mull Viola (Callistephus chinensis (L.) Nees. ،(L. Petunia hybrid (tricolor L. با نشانهاى موزاييك و لكه حلقوى روى بركها و گاهى خطوط نكروتيك روى گلها به اين ويروس (Juss. واكنش نشان مىدهد. آلودگى در خيار (Cucumis sativus L.)، خربزه (C. melo)، كيوانو 
(Luffa acutangula (L.) Roxb.) ديده شده است. ويروس در تمام (C. metuliferus E. Mey) ارقام خيار بررسى شده لكههاى موضعى نكروتيك، موزاييك سيستميك، لكه حلقوى و لكههاى كلروتيك كه با كَشت زمان نكروتيك مىشوند ايجاد مىكند. روى خربزه لكه موضعى ديده نمىشود و در تمام ارقام نشانهاى سيستميك شامل لكههاى كلروتيك، جروكيدگى برگ و لكه حلقوى غيرمنظه ديده مىشود. كدو تنبل (Cucurbita maxima L. و يا آلوده نمىشوند يا آلودگى بدون نشانه ايجاد Cucumis melo var.) مى كنند (Lisa et al. 1988b; 1990). دامنه ميزبانى طبيعى ويروس شامل كميوزه

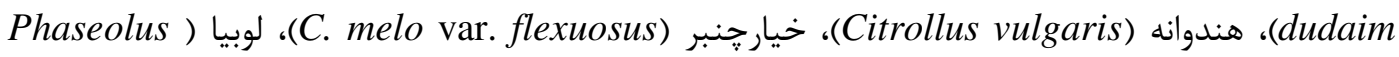
(Dacus carota L. (volgaris L. Lactuca (Amaranthus retroflexus L.) و گاوجاقكن (Convolvulus sp.) (scariola L.

\section{r-ن (- بحوه انتقال}

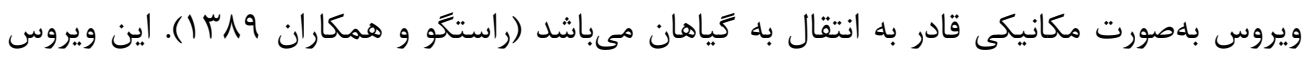

در بعضى از ميزبانها شامل Nenthamiana و . megalosiphon بذربرد است اما درصد انتقال آن پايين است (r-1 /) و كياهان حاصل از بذرهاى آلوده بدون نشانه هستند (Lisa et al. 1990). انتقال از طريق سس (Cuscuta sp.) نيز صورت گرفته است (Caciagli et al. 1989). ويروس علىرغم داشتن دامنه Cucumber mosaic ) ميزبانى وسيع از ساير ويروسهاى آلوده كننده كدوييان مانند ويروس موزاييك خيار virus, CMV موزاييك زرد كدو (Zucchini yellow mosaic virus, ZYMV) با استفاده از كياهان محك بدليل عدم ايجاد نشانها روى كدو تنبل (Cucurbita pepo) و Cucurbita maxima قابل تشخيص است. ساير N. glutinosa L. ويروسهاى ذكر شده روى اين گياهان آلودگى سيستميك ايجاد مى كنند. علاوه بر اين بلهورت آلودگى موضعى بدون ايجاد نشانههاى سيستميك به ويروس خربزه اروميه واكنش نشان مىدهد در حالى كه اين گياه به CMV آلودگى سيستميك نشان مىدهد. در حال حاضر هيجگًونه ناقل طبيعى براى ويروس شناسايى نشده است و تمام آزمونهاى انتقال با شتههاى Aphis gossypii Glover، 
Macrosiphum euphorbiae Thomas , Myzus persicae Sulzer A. craccivora C. L. Koch

Trialeurodes vaporariorum بصورت پايا، نيمهيايا و نايايا با شكست مواجه شدهاند. سفيدبالكهاى (Tetranychus urticae C.L.Koch) و و شيشك Bemisia tabaci Gennadius و Westwood (Pseudococcus citri Risso.)

\section{F Pشخصات زنوم ويروس و سازماندهى آن F}

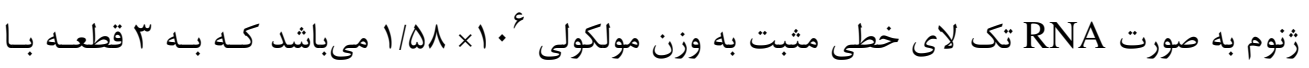

وزن مولكـــــــ poly A ) در انتهاى 'ه يا دنبالـه يلـى آ VPg (cap) تقسيم شده است. وجود سريوش (974 nt, RNA3) tail در انتهاى'ب زنوم ويروس مشخص نشده است (Rastgou et al. 2009 ). در ييكره ويروس به طول VY

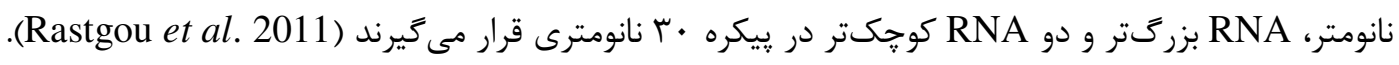
در هر سه ويروس هر يك از سه بخش زنوم داراى يك جارجوب خوانش بازدر رشته مثبت مىباشد. توانايى كد

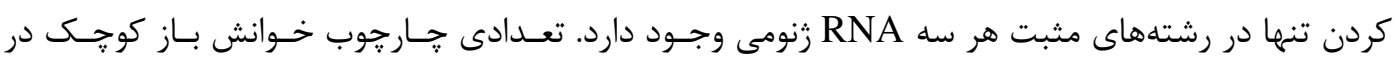
رشتهاى مكمل زنوم وجود دارد كه در بين سه ويروس حفاظت شده نيسـتند (Rastgou et al. 2009). در آزمونهاى انجام شده ميزان RNA2 و RNA3 استخراج شده تقريباً يكسان اما ميزان RNA1 در مقايسه با دو RNA ديغر بيشتر بوده است. ناحيه غير كدكننـده انتهـاى ' ها (5' Untranslated Region, 5' UTR) قطعات زنومى در ويروس خربزه اروميه با CCC شروع مىشود (Rastgou et al. 2009).

ه-جار جوبهاى خوانش باز تعيين شده در زنوم ويروس خربزه اروميه

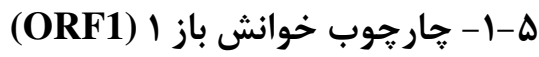

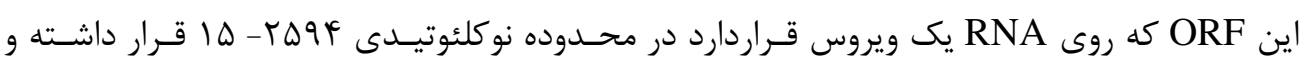

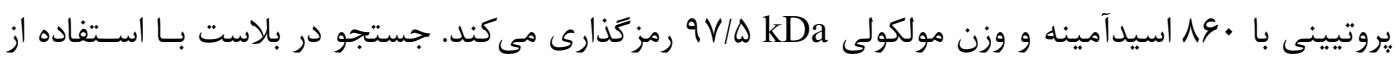
ترادفهاى اسيدآمينهى مشتق شده از خارجوب خوانش بـاز يـك و همرديـفسـازى جند گانسه آنهـا ارتبـاط معنى دارى با يروتيينهاى يليمراز (RNA dependent RNA polymerase, RdRp) دو ويـروس مخمـرى 
هـ Saccharomyces $23 S$ RNA Narnavirus, Saccharomyces 20S RNA Narnavirus Narnaviridae جنس اورمياويروس و تعدادى از ويروسهاى قارجى و باكتريايى با اسـتفاده از برنامـه CLUSTAL X نشـان داد كه f موتيف مربوط به آنزيم RNA يليمراز وابسته به RNA در بين اين ويروسها حالـت حفاظـت شـده دارند. اين موتيفها در واقع بيانكر ناحيه Palm در آنزيم RdRp مىباشند. اين موتيفها توسط افراد مختلـف شناسايى و با نامهاى متفاوتى نامگذارى شدهاند. اين ناحيه براى آناليز تعداد زيادى از ويروسهاى داراى زنـوم مثبت مفيد مىباشد (Koonin and Dolja 1993).

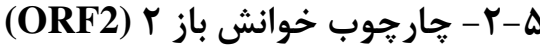

دومين خارجوب خوانش باز با محدوده نوكلئوتيدى

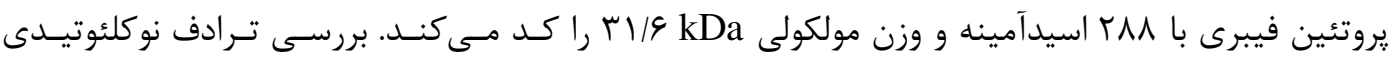
جار جوب خوانش باز Y يا ترادف اسيدآمينهى يروتيين كد شده توسـط ايـن جــار جوب در اورميـاويروسهـا بــا Movement ( استفاده از برنامه بلاست نشان داده است كه اين يروتيين به يروتيين حركت سلول بـه سـلول اعضاى جـنس Aureusvirus از تيـره Tombusviridae مقـدارى شـباهت دارد. جـار جوب (protein, MP خوانش باز r و ويروس خربزه اروميه يروتيينى را كد مى كند كه ظاهراً رابطه دورى با هـروتيين حركتى جــس اورئوسويروس دارد. اين يافته با نتايج مربوط به الكترون ميكروسكويى نيز تأييد شده است كه نشان مىدهـد محصول جار جوب خوانش باز r ويروس خربزه اروميه توبولهايى را تشكيل مىدهد كه ويريونها را دربركرفته و در حال عبور از ديواره سلولى از طريق يلاسمودسماها هستند. اين نتايج براى ويروس سى كاساوا نيز بدست آمده است (Aiton et al. 1988). از اين نظر اورمياويروسها مىتوانند با تيرهاى ويروسى Bromoviridae، Caulimoviridae و و نيـز جــنس Comoviridae قراركيرند كه يك يروتيين حركتى تقريباً 30kDa دارند و از استراتزى توبول بـراى حركـت سـلول بـه سـلول استفاده مى كنند (Margaria et al. 2016). همجنين يروتيينهاى حركتى ويروسهاى كياهى اكثراً بصـورت فسفريله شده هستند (Lee and Lucas 2001). بنابراين وجود دو باند يروتيينى حركتى نزديك به هم كه با آنتىبادى ضد توبول در آزمونهاى وسترن بلات عصاره كياهان آلوده به ويروس خربزه اروميه واكنش مىدهند 
مىتواند با تغييرات يس از ترجمه (post-translational modification) توجيـه شـود. همجنــين بعضى از جايعاههاى حفاظت شده فرضى فسفريله شدن يروتيين كيناز سى (protein kinase c) در يروتيين جار جوب خوانش باز r ديده شده است (Rastgou et al. 2009).

\section{ه-ץ- جار جوب خوانش باز ץ (ORF3)}

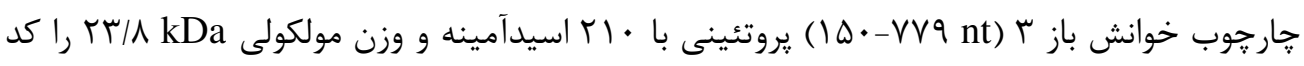
مى كند كه يروتيين يوششى (Coat protein, CP) ويروس است. همرديفسازى جند باز سه ويروس موجود در جنس اورمياويروس حفاظتشدگى محدودى را در بين سـه گونسه نشـان مسىدهـد.

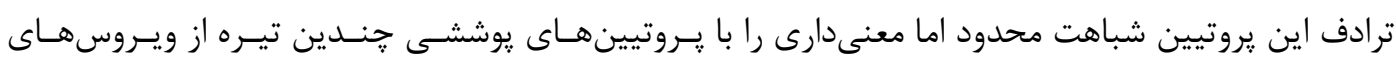
كَياهى و جـانورى از جملـه لوتئوويريـده (Luteoviridae) و نوداويريـده (Nodaviridae) نشـان مسىدهـد. جارجوب خوانش باز ץ يروتيين يوششى ويروس را كد مى كند كه يس از بيان در باكترى بعنوان يك يـروتيين نوتركيب و در كياه به كمك اكروباكتريوم در آزمونهاى وسترن بلات با اسـتفاده از آنتـىبـادى ضــ يـروتيين يوششى ويروس شناسايى شده است (Rastgou et al. 2009). براى حركت سلول به سلول و حركت در فواصل طـولانى در Nicotiana benthamiana ضـرورى اسـت. در حقيقت بـدون CP و RNA1 RNA ويروس بندرت از بركهاى مايهزنى شده حركت كرده و از طريق بافت آبكشى خود را به بركهاى بالايى مايه-

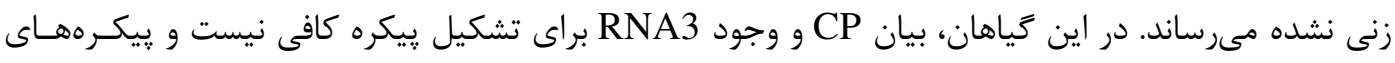
ويروس تنها زمانى تشكيل مىشوند كه RNA1 هم بيان شود و همانندسازى فعال ويـروس در داخـل سـلول اتفاق بيفتد (Crivelli et al. 2011). مشخص شده است كه ناحيه ان-ترمينال اين بروتيين منطقـه غنسى از ليزين-آرزينين (KR- rich region) كوجكى دارد كه در مونتاز بيكره ويروس، بيمارىزايى و يرآزارى ويروس نقش دارد. بدون تغيير ماندن اين ناحيه براى كيسيديوشى RNA زنومى ويروس ضرورى مىباشد. در حقيقت جهشهاى معينى در داخل اين ناحيه KR، توانايى كيسيديوشى CP را تحت تأثير قرار مىدهد. جهشيافتـهـN. هايى كه در اين ناحيه دجار جهش شده بودند قادر به تجمع در بافت مزوفيـل اسـفنجى بـرى گياهــان بودند اما فقط كاهى اوقات مىتوانستند بافت پيارانشيم نردبانى را Arabidopsis thaliana genthamiana آلوده كنند (Rossi et al. 2014). وجود اين ناحيه براى تجمع CP در هستك سلول ميزبان نيز ضرورى مى - 


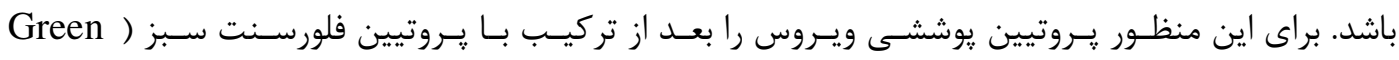
(Florescent protein به داخل سلول فرستادند و مشخص شد كه يروتيين فلورسنت سبز در هستك تجمـع ييدا مى كند. اين شواهد نقش اساسى CP در آلودگى ويروسى و ارتباط ناحيه KR را در تعيسين بافتـرايسى، دامنه ميزبانى، بيمارىزايى و تمايل به RNA نشان مىدهد و با نقـش احتمـالى ايـن يـروتيين در بـازدارى از خاموشى زن نيز در ارتباط است (Rossi et al. 2015). اين يروتيين در مقايسه بــا يـروتيين فيبـرى كـه در حركت ويروس نقش دارد غلظت بيشترى را در آزمون وسترنبلات يروتيين اسـتخراج شـده از كَياهــان نشـان مى دهد (Rastgou et al. 2009).

\section{9-منشا احتمالى اورمياويروسها}

حفاظتشدكى ترادفها و خويشاوندىهاى فيلوزنتيكى بدست آمده براى RdRp و MP نشان مىدهد كه اورمياويروسها زنومهاى تغييريافتهاى (chimeric) را دارند كه احتمالاً از قطعات RNA از حداقل دو يا سه منبع متفاوت حاصل شدهاند (Rastgou et al. 2009). محتملترين سناريو براى منشاء اورمياويروسها مىتواند اين باشد كه يك نارناويروس فاقد يروتيين يوششى از يك قارج بيمارىزا يا اندوفيت كياهى در اثر كسب يروتيين حركتى و يروتيين يوششى از ويروسهاى گياهى به يك ويروس كياهى تبديل شده است (Rastgou et al. 2009). بنظر مىرسد كه زن يروتيين حركتى از يكى از اعضاء تيره تومبوسويريده (Tombusviridae) گرفته شده است درحاليكه زن يروتيين يوششى ممكن است از همان منبع يا به احتمال قوى از يك ويروس ديكر اخذ شده باشد. وجود منشاءهاى مختلف براى زنهاى متفاوت نشان مىدهد كه يك زنوم ويروسى از طريق نوتركيبى بين ويروسهاى مختلف كه در بين ويروسهاى گياهى متداول است بوجود آمده است. يروتيينهاى حركتى در آلودگى سيستميك گياهان بوسيله گروه وسيعى از ويروسها شامل تيرههايى از ويروسهاى RNA دار و نيز جمينىويروسهاى حاوى DNA ارتباطى ندارند نقش دارند (Koonin et al. 1991). بنابراين حركت افقى زن يروتيين حركتى كه براى انتشار سيستميك يك ويروس ضرورى است (و بنابراين در يك زنوم ويروسى كه آنرا جديداً اخذ كرده است براحتى تثبيت مىشود) جاى شك و ترديد دارد. ويروسهايى كه در آنها زنهاى يروتيين يليمراز و يروتيين يوششى منشاءهاى متفاوتى دارند نشان دهنده نوتركيبى در طى تكامل گروههاى ويروسى مربوطه نيز مىباشند. 
بنابراين تغييرات ايجاد شده (chemrism) در اورميا ويروسها بهنظر مىرسد كه منحصر بهفرد باشد جرا كه هر سه قطعه زنوم ويروس به احتمال زياد از يك منبع جداكانه منشاء گرفتهاند كه نشان مىدهد مكانيسم احتمالى تكامل اين قطعات زنومى است تا نوتركيبى (Rastgou et al. 2009). تئورى ديكر اين است كه منشاء اورمياويروسها احتمالاً دربردارنده اخذ RNAهاى زيرزنومى كدكننده يروتيينهاى حركتى و يوششى از دو ويروس كياهى متفاوت يا احتمالاً دو RNA زيرزنومى از يك ويروس است كه اين RNA ها قطعات زنومى اجداد اورمياويروسها مىباشند (Rastgou et al. 2009). علاوه براين بلنظر مىرسد كه يروتيين يليمراز اورمياويروس از يك ويروس قارجى مشتق شده است. ارتباطات تكاملى بين ويروسهاى كياهى و ويروسهاى قارجى قبلاً نيز تزارش شدهاند اما بنظر مىرسد كه اين ارتباطات با مورد اورمياويروسها در خصوصيات مهمى تفاوت دارند. اخيراً ويروس جديدى از قارج. Botrytis sp جدا شده از انكور در اسيانيا گزارش شده است كه مشخص شده يروتيين يليمراز اين ويروس شباهت بالايى با پروتيين يليمراز OuMV دارد. اين ويروس جديد BOLV) Botrytis Ourmia-like virus) نامگذارى شده است كه از لحاظ فيلوزنتيكى به جنس Narnavirus و Narnaviridae Ourmiavirus شباهت زيادى دارد تا به جنس Marnaviridae احتمال مىرود كه اين ويروس جديد يك رابط بين ويروسهاى قارجى تيره Narnaviridae و اورمياويروسهاى كياهى باشد (Donaire et al. 2016). جنس اورمياويروس يك جنس حقيقى گیاهى مىباشد. مىتوان اين جنس را با توجه به اينكه داراى RNAزنومى سه قطعهاى است كه دو قطعه آن يروتيين حركتى و يروتيين يوششى را كد مى كنند و نيز ميزبان و نحوه زندكى متفاوتى با نارناويروسها دارد در تيره جديدى تحت عنوان Ourmiaviridae قرارداد. يك سناريوى احتمالى اين است كه زنهاى مربوط به يروتيين يوششى و يروتيين حركتى از يك ويروس كياهى به يك ويروس قارجى به صورت افقى منتقل شده و ويروس قارجى را قادر به آلوده كردن گياه كرده است. سناريوى احتمالى ديكر اين است كه يك جد اورمياويروسى قطعات زنومى دو و سه خود را در هنگام آلوده كردن ميزبان قارجى از دست داده و تيرهى Narnaviridae را بلوجود آورده است كه قادر به آلوده كردن قارجها مىباشند (Rastgou et al. 2009). 


$$
\begin{aligned}
& \text { نتيجلَّيرى و پِيشنهاد } \\
& \text { ويروس خربزهى اروميه همراه با ويروس اييروس كيلاس و ويروس سى كاساوا در جنس اورمياويروس } \\
& \text { قرار داده شده است. تركيب زنومى منحصر بفرد و خويشاوندى دور بين زنهاى يروتيين (Ourmiavirus) } \\
& \text { يليمراز، يروتيين حركتى و يروتيين يوششى اورمياويروسها و زنهاى همولوى از ساير ويروسهاى گياهى } \\
& \text { قوياً نشان مىدهد كه اورمياويروسها بايستى در يك تيرهى جديد ويروسى قرارگيرند. اين نتيجهَيرى با } \\
& \text { مورفولوزى منحصر بفرد بيكرههاى اين ويروسها مورد تأييد قرار مى گيرد. احتمالاً ويروسهاى ديكرى نيز } \\
& \text { وجود دارند كه بايد در اين تيره قرار گيرند، بنابراين يزوهشهاى بيشترى براى يافتن ويروسهاى گياهى } \\
& \text { خويشاوند آنها ضرورى هستند، تا با درك بهتر قرابت زنتيكى، دامنه ميزبانى و روشهاى انتقال و انتشار آنها } \\
& \text { روشهاى مناسب مديريت اين ويروسهاى انگل كياهى را بيشنهاد داد. }
\end{aligned}
$$

\section{References}

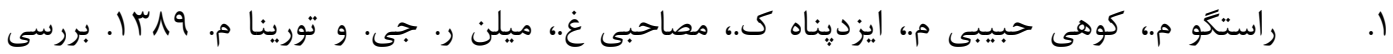
ڤارهاى از خصوصيات بيولوزيكى ويروس خربزه اروميه (Ourmia melon virus, OuMV)، وقوع آن در جند استان ايران و ارزيابى واكنش ارقام محلى و تجارى كدو و خيار نسبت به ويروس. دانش كياهيرشكى /يران أ):

2. Accotto G. P., Riccioni L., Barba M., Lisa V. and Boccardo G. 1990. Ourmia melon and Epirus cherry viruses, two representatives of a new virus group. Proceedings of $8^{\text {th }}$ International Congress of Virology, Berlin, Germany, p 448.

3. Aiton M. M., Lennon A. M., Roberts I. M. and Harrison B. D. 1988. Two new cassava viruses from Africa. Abstracts book of $5^{\text {th }}$ International Congress of Plant Pathology, Kyoto, Japan, p 43.

4. Caciagli P., Luisoni E., Vecchiatti M., Lisa V. and Parvizi R. 1989. Ourmia melon virus: update on its biology. Proceedings of $6^{\text {th }}$ conference, Recent Advances in Vegetable Virus Research, Asilomar, California, USA, p 9.

5. Covelli L., Coutts R. H. A., Di Serio F., Citir A., Açkgöz S., Hernández C., Ragozzino A. and Flores R. 2004. Cherry chlorotic rusty spot and Amasya cherry diseases are associated with a complex pattern of mycoviral-like double-stranded 
RNAs. Characterization of a new species in the genus Chrysovirus. Journal of General Virology 85:3389-3397.

6. Crivelli G., Ciuffo M., Genre A., Masenga V. and Turina M. 2011. Reverse genetic analysis of ourmiaviruses reveals the nucleolar localization of the coat protein in Nicotiana benthamiana and unusual requirements for virion formation. Journal of Virology 85:5091-5104

7. Donaire L., Rozas J. and Ayllón M. A. 2016. Molecular characterization of Botrytis ourmia-like virus, a mycovirus close to the plant pathogenic genus Ourmiavirus. Virology 489:158-164.

8. Gholamalizadeh R., Vahdat A., Hossein-Nia S. V., Elahinia A. and Bananej K. 2008. Occurrence of Ourmia melon virus in the Guilan Province of Northern Iran. Plant Disease 92:1135-1135.

9. Koonin E. V. and Dolja V. V. 1993. Evolution and taxonomy of positive-strand RNA viruses: implications of comparative analysis of amino acid sequences. Critical Reviews in Biochemistry and Molecular Biology 28:375-430.

10. Koonin E. V., Choi G. H., Nuss D. L., Shapira R. and Carrington J. C. 1991. Evidence for common ancestry of a chestnut blight hypovirulence-associated doublestranded RNA and a group of positive-strand RNA plant viruses. Proceedings of the National Academy of Sciences USA 88:10647-10651.

11. Lee J-Y. and Lucas W. J. 2001. Phosphorylation of viral movement proteinsregulation of cell-to-cell trafficking. Trends in Microbiology 9:5-8.

12. Lisa V., Milne R. G. and Parvizi R. 1990. Ourmia melon virus and other cucurbit viruses in west Azerbaijan, Iran. FAO Plant Protection Bulletins 38:218219.

13. Lisa V., Milne R. G., Accotto G. P., Boccardo G., Caciagli P. and Parvizi R. 1988a. Ourmia melon virus, a virus from Iran with novel properties. Annals of Applied Biology 112: 291-302.

14. Lisa V., Milne R. G., Boccardo G., Accotto G. P. and Luisoni E. 1988b. Ourmia melon virus, possible representative of a new virus group. Proceeding of $5^{\text {th }}$ International congress of Plant Pathology, Kyoto, Japan, p 40.

15. Margaria P., Anderson C. T., Turina M. and Rosa C. 2016. Identification of Ourmiavirus $30 \mathrm{~K}$ movement protein amino acid residues involved in 
symptomatology, viral movement, subcellular localization and tubule formation. Molecular Plant Pathology. doi:10.1111/mpp.12348.

16. Milne R. G. and Masenga V. 1988. Particle structure of Ourmia melon virus, a virus from Iran representing a new taxonomic group. International Symposium of Plant Pathology, Beijing, China, p 549.

17. Milne R. G. and Masenga V. 1989. Structure and cytopathology of Ourmia melon virus, a virus from Iran with novel properties. Proceedings of $6^{\text {th }}$ conference, Recent Advances in Vegetable Virus Research, Asilomar, California, USA, p 21.

18. Rastgou M., Habibi M. K., Izadpanah K., Masenga V., Milne R. G., Wolf Y. I., Koonin E. V. and Turina M. 2009. Molecular characterization of the plant virus genus Ourmiavirus and evidence of inter-kingdom reassortment of viral genome segments as its possible route of origin. Journal of General Virology 90:2525-2535.

19. Rastgou M., Turina M. and Milne R.G. 2011. Family Ourmiaviridae. pp 11771180. In: King A. M. Q., Adams M. J., Carstens E. B., Lefkowitz E (eds.) Virus Taxonomy. Ninth Report of the International Committee on Taxonomy of Viruses. Elsevier Academics Press, London, UK.

20. Rossi M., Genre A. and Turina M. 2014. Genetic dissection of a putative nucleolar localization signal in the coat protein of Ourmia melon virus. Archives of Virology 159:1187-1192.

21. Rossi M., Vallino M., Abbà S., Ciuffo M., Balestrini R., Genre A. and Turina M. 2015. The importance of the KR-rich region of the coat protein of Ourmia melon virus for host specificity, tissue tropism, and interference with antiviral defense. Molecular Plant Microbe Interactions 28:30-41. 